biologicai risk factors in the lowest third of childhood socioeconomic conditions, examination of these factors in adulthood alone may obscure the earlier effects of such risk factors. For example, earlier development of adverse concentrations of low density lipoprotein cholesterol in subjects in the lowest third of childhood socioeconomic conditions than in subjects in the highest third might put those in the lowest third at higher risk as adults. Thus to understand the mechanisms that underlie the association seen in this study it will be necessary to have information on differences in the course of risk factors, from childhood to adulthood, in subjects in different socioeconomic strata.

The impact of prevalent disease on this association also requires some comment. Although it is true that adjustment for a previous diagnosis of ischaemic heart disease substantially weakens the association between socioeconomic conditions in childhood and the risk of ischaemia on exercise, this should not be interpreted as an indication that prevalent disease is responsible for the association. Brcause the report of socioeconomic conditions in child rood is an account of events that happened before ischaemic heart disease developed, socioeconomic conditions in childhood may be a causal variable, one of the consequences of which is the development of ischaemic heart disease. One hypothesis is that ischaemic heart disease develops earlier in those with low socioeconomic state during childhood.

Thus possible explanations of the observed results are that, in the cohorts of men studied, risk factors for ischaemic heart disease developed earlier in those with low socioeconomic state in childhood or that clinical and subclinical disease presented earlier, or both. Barker et al found that systolic blood pressure in 10 year olds was inversely related to birth weight, suggesting that hypertension and its complication may have developed earlier in subjects from the lower socioeconomic strata, which have higher rates of low birth weight. ${ }^{21}$ The Kuopio ischaemic heart disease study is examining the prevalence and progression of carotid atherosclerosis as a function of, among other things, socioeconomic conditions in childhood, and it will consider earlier development and faster progression of disease in subjects with low socioeconomic state during childhood.
This work was supported by the Finnish Academy and the Sigrid Juselius Foundation.

1 Syme SL, Berkman LF. Social class, susceptibility and sickness. Am $\mathcal{f}$ Epidemiol 1976;104:1-8.

2 Antonovsky A. Social class, life expectancy and overall mortality. Millbank Mem Fund $Q$ 1967;45:31-73.

3 Department of Health and Human Services. Inequalities in health. Report of a research working group. London: Department of Health and Social Services, 1980. (Black report.)

4 Haan MN, Kaplan GA. The contribution of socioeconomic position to minority health. In: Secretary's Task Force on Black and Minority Health. Report. Vol 2. Crosscutting issues in minority health. Washington, DC: Department of Health and Human Services, 1985.

5 Marmot MG, Rose G, Shipley M, Hamilton PJS. Employment grade and coronary heart disease in British civil servants. $\mathcal{J}$ Epidemiol Community Health 1978:32:244-9.

6 Salonen JT. Socioeconomic status and risk of cancer, cerebral stroke, and death due to coronary heart disease and any disease: a longitudinal study in eastern Finland. $\mathcal{f}$ E pidemiol Community Health 1982;36:294-7.

7 Kaplan GA. Psychosocial aspects of chronic illness: direct and indirect associations with ischemic heart disease mortality. In: Kaplan RM, Criqui $\mathrm{MH}$, eds. Behavioral epidemiology and disease prevention. New York: Plenum, 1985:237-69.

8 Holme I, Hegeland A, Hjermann II, Leren P. The Oslo Study: social indicators, risk factors and mortality. In: Bostrum $\mathrm{H}$, Ljungfstedt $\mathrm{N}$, eds. Medical aspects of mortality statistics. Stockholm: Almquist Wiksell, 1981.

9 Forsdahl A. Are poor living conditions in childhood and adolescence an important risk factor for arteriosclerotic heart disease? Br f Prev Soc Med 1977;31:91-5.

10 Forsdahl A. Living conditions in childhood and subsequent development of risk factors for arteriosclerotic heart disease. The cardiovascular survey in risk factors for arteriosclerotic heart disease. The cardiovascular
Finnmark 1974-75. F Epidemiol Community Health 1978;32:34-7.

11 Notkola V, Punsar S, Karvonen MJ, Haapakoski J. Socio-economic conditions in childhood and mortality and morbidity caused by coronary heart ditions in childhood and mortality and morbidity caused by coronary
disease in adulthood in rural Finland. Soc Sci Med 1985;21:517-23.

12 Barker DJP, Osmond C. Infant mortality, childhood nutrition, and ischaemic heart disease in England and Wales. Lancet 1986;i:1077-81.

13 Barker DJP, Osmond C. Death rates from stroke in England and Wale predicted from past maternal mortality. BrMed F 1987;295:83-6.

14 Arnesen E, Forsdahl A. The Tromsø heart study: coronary risk factors and their association with living conditions during childhood. I Epidemio Community Health 1985;39:210-4.

15 Keys A. Seven countries. A multivariate analysis of death and coronary hean disease. Cambridge, Massachusetts: Harvard University Press, 1980.

16 Carmines EG, Zeller RA. Reliability and validity assessment. London: Sage, 1979.

17 Salonen JT, Lakka T. Assessment of physical activity in population studiesvalidity and consistency of the methods in the Kuopio ischaemic heart disease risk factor study. Scandinavian foumal of Sports Science 1987;9: disease

18 Ihanainen M, Salonen R, Seppänen R, Salonen JT. Nutrition data collection in the Kuopio ischaemic heart disease risk factor study: nutrient intake of middle-aged eastern Finnish men. Nutr Res 1989;9:597-604.

19 Salonen R, Seppänen K, Rauramaa R, Salonen JT. Prevalence of carotid atherosclerosis and serum cholesterol levels in eastern Finland. Arterio sclerosis 1988;8:788-92.

20 SAS Institute. SAS user's guide: statistics. Version 5 edition. Cary, North Carolina: SAS Institute, 1985.

21 Barker DJP, Osmond C, Golding J, Kuh D, Wadsworth MEJ. Growth in utero, blood pressure in childhood and adult life, and mortality from cardiovascular disease. $\mathrm{Br} \mathrm{Med} \mathcal{F}$ 1989;298:564-7.

(Accepted 24 August 1990)

\title{
Famine in southern Ethiopia 1985-6: population structure, nutritional state, and incidence of death among children
}

\author{
Bernt Lindtjørn
}

\section{Abstract}

Objective-To assess the effects of drought on mortality in children.

Design-Prospective epidemiological study forming part of nutritional monitoring during famine relief work.

Setting-24 Food distribution sites in Arero and Borana provinces in southern Ethiopia.

Patients-A monthly average of 14173 and 5334 children under 5 were examined in 1985 and 1986, respectively. Altogether 148966 child months (105872 for 1985 and 43094 for 1986) were available for analysis.

Intervention-The families of all children were supplied with food each month. Basic medical care was also provided.

Main outcome measure-Mortality in children under 5.
Results-A $40 \%$ increase in crude mortality was observed among children living in traditional and stable societies. The severe consequences were observed mainly among children living in relief shelters, where a threefold to fourfold increase in crude mortality was recorded among children. Increased childhood mortality was also associated with high prevalence of malnutrition, living in the most arid areas, and the dry season. A long period of food aid was needed to normalise the nutritional state, especially for children living in relief shelters.

Conclusions-The most severe consequences of the widespread famine that occurred in the Arero and Borana provinces of southern Ethiopia during 1985-6 were seen among children living in relief shelters. Early food intervention may decrease the scale of migration and thus also reduce the severe consequences of a famine. 


\section{Introduction}

Several studies have assessed human mortality in relation to drought and famine in Africa. In the 1970s a threefold increase in crude mortality among nomads affected by drought was reported from Mauritania, and similar figures have been published from northern Ethiopia. ${ }^{2}$ During the Ogaden famine of 1973-4 pastoralist Somalis experienced higher mortality than agriculturalist ethnic groups. ${ }^{3}$ Very high death rates have been reported from famine relief shelters in Somalia, Ethiopia, and the Sudan. ${ }^{46}$ Because the population in relief shelters represents people who moved from their homes they may form a biased selection of the community affected by drought.

Infectious diseases represent the main cause of sickness and death at the time of famines, ${ }^{568}$ but during more normal years confounding variables seem to influence the association between malnutrition and infection. ${ }^{910}$ These variables include season, ${ }^{11}$ family structure, ${ }^{12}$ population movement, ${ }^{13}$ and living conditions. ${ }^{14}$ The conflicting results of studies in children with regard to the relation between anthropometric measurements and risk of infection and death ${ }^{15-18}$ may reflect the influence of such environmental variables. ${ }^{5}$

During 1984-6 southern Ethiopia was affected by severe drought and famine. The present study was part of the nutritional monitoring established during relief work in the drought affected Arero and Borana provinces. Its main objective was to assess the effects of drought on crude childhood mortality, and it also sought information on the relation between death rate and social structure, nutritional state, and some environmental characteristics.

\section{Patients and methods}

STUDY AREA AND POPULATIONS

The seminomadic Boran pastoralists depend on cattle herding and live in the Arero and Borana provinces in southern Ethiopia (fig 1), areas that receive little and unevenly distributed rain. Pasture and water are related to the local rainfall pattern. ${ }^{19}$ The main rainy season lasts from mid-March to May and the small rains are in October. Least rain falls in the east and the lowlands. The Boran have suffered numerous droughts and expect intermittent disasters and livestock loss; a complicated generation system regulates their daily life. ${ }^{2021}$ In the past decades traditional modes of managing during periods of drought may have been weakened, so that people more often move to urban centres at times of food shortages. ${ }^{22}$ Out of an estimated population of $250000,,^{2123}$ about 25000 of the Boran $(10 \%)$ moved to relief shelters during the 1984-5 drought (unpublished data).

The study population consisted of children aged 1-5

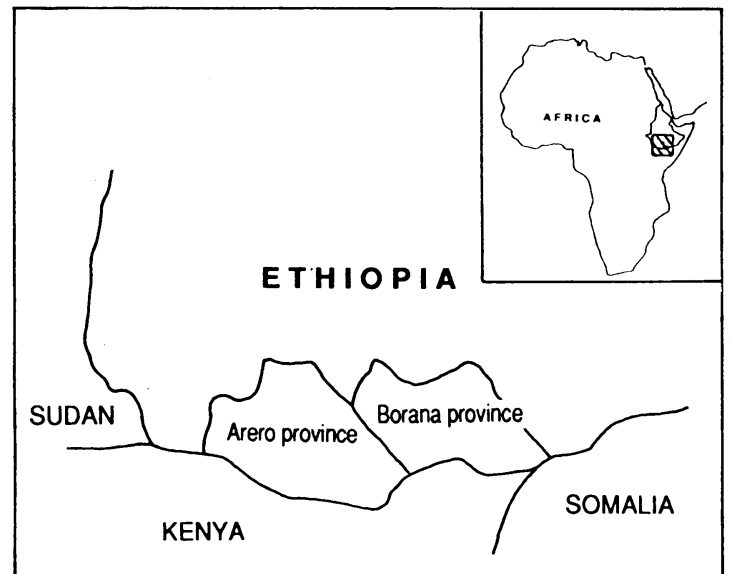

FIG 1-Map of southern Ethiopia showing Arero and Borana provinces years. Most of the children in this study belonged to the Boran ethnic group, but a few were of the Arsi, Somali, Gebra, or Gerri ethnic groups. On average 14173 children a month were examined in 1985 and 5334 in 1986. Altogether 148966 child months (105872 for 1985 and 43094 for 1986) were available for analysis from the 24 food distribution sites.

\section{NUTRITIONAL RELIEF WORKS}

The choice of locations for food distribution was based on initial nutritional surveys of the communities affected by drought. ${ }^{24}$ Families with malnourished children or families who were defined as poor by the local community were included in the food distribution programme, and all families in the relief shelters were registered as beneficiaries. Each family was given a monthly ration of grain, dried skimmed milk, and vegetable oil to provide an estimated $6688 \mathrm{~kJ}$ $(1600 \mathrm{kcal})$ per person per day. Additional rations were given to the malnourished children. Basic medical care as well as vaccinations against measles were provided at each distribution site. In addition, each child was given a capsule of vitamin A (200000 IU) every three months.

Standardised procedures were used to measure weight and height. Weight was recorded monthly from March 1985 to December 1986, and height was measured every second month. Anthropometric standards issued by the National Center for Health Statistics, Washington, DC, were used to calculate the weight for height ratio. ${ }^{25}$ Wasting was defined as weight for height less than $80 \%$ of the reference median. ${ }^{26}$

TABLE I-Incidence of death and prevalence of wasting among children aged 1-5 years in Arero and Borana provinces, Ethiopia

\begin{tabular}{|c|c|c|c|c|}
\hline & \multicolumn{2}{|c|}{ Arero province } & \multicolumn{2}{|c|}{ Borana province } \\
\hline & 1985 & 1986 & 1985 & 1986 \\
\hline \multicolumn{5}{|c|}{ Deaths $/ 100$ child months: } \\
\hline Pastoralists & 0.55 & 0.42 & $0 \cdot 81$ & $1 \cdot 16$ \\
\hline Shelter population & $2 \cdot 38$ & 0.52 & $2 \cdot 17$ & No data \\
\hline Agropastoralists & $0 \cdot 39$ & $0 \cdot 24$ & No data & No data \\
\hline \multicolumn{5}{|c|}{ Mean monthly prevalence of malnutrition: } \\
\hline Pastoralists & $4 \cdot 1$ & $3 \cdot 3$ & $13 \cdot 0$ & $3 \cdot 1$ \\
\hline Shelter population & $13 \cdot 7$ & $5 \cdot 7$ & $20 \cdot 4$ & No data \\
\hline Agropastoralists & $3 \cdot 7$ & $5 \cdot 3$ & & \\
\hline
\end{tabular}

\section{STAFF}

Ten teams, each with five members, distributed the food and collected the data. The team members had completed 10-12 years of formal education and were familiar with the culture and language of the famine victims. In preparation for the work the team members received three weeks of training with emphasis on basic nutrition, food distribution practices, and data collection procedures. Nurses supervised the teams, regularly checking the recording procedures and measuring tools.

\section{DATA COLLECTION AND ANALYSIS}

Data collection was standardised and included information on weight, height, and number of deaths of registered children during the preceding 30 days. The social environment of the children was recorded either as traditional pastoralist, shelter population (mainly Boran pastoralists who moved to urban centres), or agropastoralist (practising both subsistence farming and cattle husbandry). Mortality was recorded as number of deaths per 100 child months; wasting was recorded as the monthly prevalence (in percentages). The monthly statistics from each distribution site formed the basis of this paper.

The influence of drought on the population was estimated by comparing the 1985 and 1986 malnutrition and death rates; 1986 represented the post- 
drought period with normalisation of nutritional state (table II, fig 2). Measurements of nutritional state and recordings of deaths were made regularly, following the same children during the whole period of observation, but the duration of the study varied from place to place (table II).

Data analysis and statistical evaluation were by the SPSS PC+ package. ${ }^{27}$ The data were weighted for mean number of children at the distribution site, and means were compared with the $t$ test and proportions by the $\chi^{2}$ test or Fisher's exact test. The relative risk with $95 \%$ confidence intervals and differences in regression line characteristics were analysed as recommended by Armitage. ${ }^{28} \mathrm{p}$ Values $<0.05$ were considered significant. The data set was complete for all variables except the variable mortality; the monthly mortality is missing in $21 \%$ of the children under surveillance, but these children did not differ from the average in regard to any of the other variables.

\section{Results}

\section{MAGNITUDE OF FAMINE}

Table I shows the average mortality and prevalence of wasting for the different population groups in 1985 and 1986. For the whole study population the death rate among children was twice as high in 1985 as $1986(1.08 \% v 0.48 \%)$. The relative risk of death in 1985 was significantly increased both for the pastoralist and the shelter population in the Arero province, but no such increase was seen among the pastoralists in Borana province (table III). The relative risk for death was significantly higher among the children living in shelters than among children of the traditional pastoralist and agropastoralist groups (table III).

Figure 2 shows the mean monthly prevalence of malnutrition and mortality among the traditional pastoralist, shelter, and agropastoralist groups. The nutritional recovery rate in the traditional pastoralist group was faster than in the shelter population. Children in shelters showed by far the highest prevalence of wasting, especially during 1985. Similarly, the monthly mortality among those in the shelters remained higher than for the traditional pastoralist and agropastoralist groups, particularly during the first six months of nutritional intervention.

\section{RELATION OF MORTALITY TO MALNUTRITION}

Communities where children showed high prevalence of wasting also had high mortality, but the

TABLE II - Monthly incidence of death and prevalence of wasting at 24 food distribution sites in southern Ethiopia

\begin{tabular}{|c|c|c|c|c|c|}
\hline & Population structure & $\begin{array}{l}\text { Mean monthly } \\
\text { No of } \\
\text { children }\end{array}$ & $\begin{array}{l}\text { No of months } \\
\text { of consecutive } \\
\text { observations }\end{array}$ & $\begin{array}{c}\text { Mean death rate } \\
\text { (per } 100 \\
\text { child months) }\end{array}$ & $\begin{array}{c}\text { Mean } \\
\text { prevalence of } \\
\text { wasting }(\%)\end{array}$ \\
\hline \multicolumn{6}{|l|}{ Arero province: } \\
\hline Jijiddu & Shelter & 565 & 22 & $1 \cdot 70$ & $15 \cdot 73$ \\
\hline Dillo & Shelter & 588 & 19 & 0.97 & $5 \cdot 45$ \\
\hline Hidi Ale & Agropastoralists & 895 & 20 & $0 \cdot 30$ & $4 \cdot 72$ \\
\hline Ade galchat & Pastoralists & 803 & 20 & $0 \cdot 70$ & $3 \cdot 14$ \\
\hline Birnadar & Pastoralists & 506 & 7 & $0 \cdot 18$ & $3 \cdot 56$ \\
\hline Dara & Pastoralists & 1098 & 10 & $0 \cdot 50$ & $3 \cdot 41$ \\
\hline Bube & Pastoralists & 501 & 3 & $0 \cdot 00$ & $2 \cdot 46$ \\
\hline Matagafarsa & Pastoralists & 1212 & 13 & 0.58 & $4 \cdot 74$ \\
\hline Web & Pastoralists & 585 & 7 & $0 \cdot 30$ & $5 \cdot 35$ \\
\hline Borbor & Pastoralists & 498 & 1 & Not registered & 1.81 \\
\hline Dololo Makal & Shelter & 1491 & 9 & $2 \cdot 84$ & $12 \cdot 34$ \\
\hline Erder & Pastoralists & 419 & 7 & 0.42 & $3 \cdot 51$ \\
\hline Dubluk & Pastoralists & 557 & 8 & 0.52 & $3 \cdot 47$ \\
\hline Dikitcha & Pastoralists & 662 & 8 & 0.35 & $4 \cdot 76$ \\
\hline Tuka & Agropastoralists & 570 & 8 & $0 \cdot 22$ & $3 \cdot 50$ \\
\hline Argenne & Agropastoralists & 463 & 7 & 0.51 & $3 \cdot 80$ \\
\hline Mudi Ambo & Pastoralists & 212 & 7 & $0 \cdot 42$ & 4.57 \\
\hline Dambi & Pastoralists & 470 & 6 & 0.55 & $4 \cdot 04$ \\
\hline Mado & Pastoralists & 414 & 6 & 0.64 & 4.02 \\
\hline \multicolumn{6}{|l|}{ Borana province: } \\
\hline Hidedo & Shelter & 778 & 9 & $2 \cdot 18$ & $20 \cdot 40$ \\
\hline Hudet & Pastoralists & 346 & 8 & $0 \cdot 70$ & $15 \cdot 71$ \\
\hline Wachille & Pastoralists & 266 & 17 & $1 \cdot 18$ & $6 \cdot 70$ \\
\hline Melka Guba & Pastoralists & 248 & 19 & 1.02 & $7 \cdot 00$ \\
\hline Hadessa & Pastoralists & 146 & 19 & $0 \cdot 84$ & $5 \cdot 35$ \\
\hline
\end{tabular}
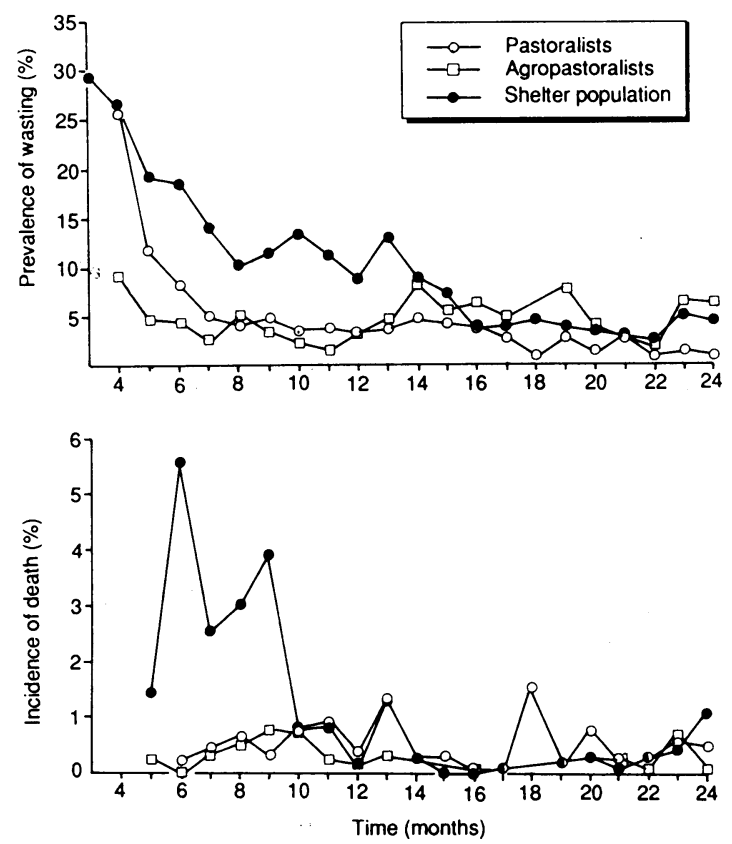

FIG 2-Mean monthly wasting rate (top) and death rate (bottom) for pastoralists, agropastoralists, and shelter population in southern Ethiopia

regression lines of mortality on wasting differed for the shelter population and traditional pastoralist and agropastoralist communities (fig 3). This difference was significant both about the slope $(t=5 \cdot 28 ; \mathrm{p}<0.001)$ and at the intercept on the y axis $(t=96.33 ; \mathrm{p}<0.001)$.

\section{RELATION OF MORTALITY, ALTITUDE AND SEASON}

In general, in 1985 and 1986 the risk of death among children was higher in the eastern and more arid Borana province than in the Arero province (tables II, III). Children living in highland shelters had a greater

TABLE III - Factors associated with risk for death among children aged 1-5 years

\begin{tabular}{|c|c|c|c|}
\hline & $\begin{array}{c}\text { Relative } \\
\text { risk }\end{array}$ & $\begin{array}{c}95 \% \\
\text { Confidence } \\
\text { interval }\end{array}$ & $\mathrm{p}$ Value \\
\hline Year $(1985 v 1986)$ & $2 \cdot 26$ & 1.89 to 2.70 & $<0.0001$ \\
\hline \multicolumn{4}{|l|}{$\begin{array}{l}\text { Population structure (Shelter } v \\
\text { traditional groups) }\end{array}$} \\
\hline & $3 \cdot 84$ & 3.42 to 4.32 & $<0.0001$ \\
\hline 1985 & $4 \cdot 37$ & 3.85 to 4.96 & $<0.0001$ \\
\hline 1986 & $1 \cdot 14$ & 0.76 to 1.70 & $>0.05$ \\
\hline \multicolumn{4}{|l|}{ Geographical location (region): } \\
\hline 1985, Borana $v$ Arero & 1.44 & 1.21 to 1.71 & $<0.0001$ \\
\hline 1986, Borana $v$ Arero & $2 \cdot 91$ & 1.99 to 4.25 & $<0.0001$ \\
\hline Borana, $1985 v 1986$ & $1 \cdot 26$ & 0.86 to 1.84 & $>0.05$ \\
\hline Arero, $1985 v 1986$ & $2 \cdot 55$ & $2 \cdot 08$ to $3 \cdot 12$ & $<0.0001$ \\
\hline
\end{tabular}

risk of death during 1985. Table IV shows that the risk of death was increased during dry seasons except for the traditional pastoralist and agropastoralist societies in 1985, when it was increased during the rainy season.

\section{Discussion}

This study confirms earlier reports of widespread famine in the Arero and Borana provinces of southern Ethiopia during 1985-6.. ${ }^{2429}$ Although children living in traditional and stable societies were affected by the drought, the severe consequences were noticed primarily among those living in relief shelters, where we observed a threefold to fourfold increase in mortality in children compared with that in traditional pastoralist and agropastoralist groups. Even the pastoralist population of Arero had a $40 \%$ increase of deaths in children during 1985 compared with 1986.

The mortality in 1985 in the shelter populations in Arero and Borana was comparable to that reported from relief shelters in the Sudan. ${ }^{5}$ The present study may thus be representative of the recent severe famines 


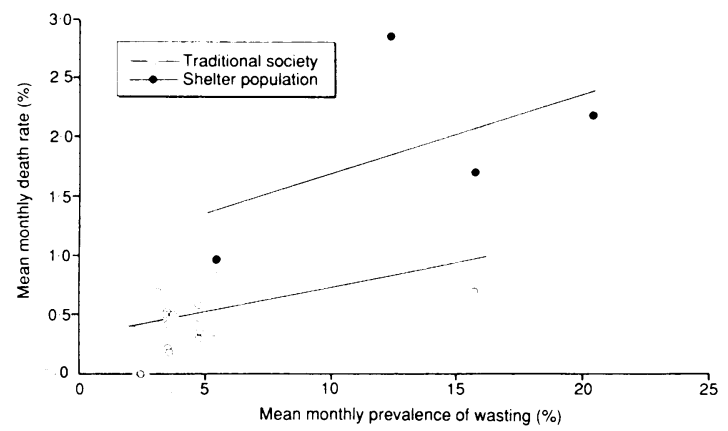

FIG 3-Relation between mortality and prevalence of wasting in shelter population $(+)$ and traditional societies $(\square)$ in southern Ethiopia

TABLE IV - Influence of year, season, and altitude in Arero province on risk of death among children aged 1-5 years

\begin{tabular}{|c|c|c|c|}
\hline Population structure and variables & $\begin{array}{l}\text { Relative } \\
\text { risk }\end{array}$ & $\begin{array}{c}95 \% \\
\text { Confidence } \\
\text { interval }\end{array}$ & $\mathrm{p}$ Value \\
\hline \multicolumn{4}{|c|}{ Pastoralist and agropastoralist populations } \\
\hline $1985 v 1986$ & 1.40 & 1.07 to 1.82 & $<0.05$ \\
\hline \multicolumn{4}{|l|}{ Season: } \\
\hline 1985 , Wet $v$ dry season & $1 \cdot 86$ & $1 \cdot 46$ to $2 \cdot 37$ & $<0.0001$ \\
\hline 1986 , Wet $v$ dry season & $0 \cdot 26$ & 0.13 to 0.54 & $<0.0001$ \\
\hline \multicolumn{4}{|l|}{ Altitude: } \\
\hline 1985 , Lowland $v$ highland & 0.92 & $0 \cdot 72$ to $1 \cdot 18$ & $>0.05$ \\
\hline 1986, Lowland $v$ highland & 0.77 & 0.41 to 1.43 & $>0.05$ \\
\hline \multicolumn{4}{|c|}{ Shelter population } \\
\hline $1985 v 1986$ & 4.53 & $3 \cdot 26$ to $6 \cdot 28$ & $<0.0001$ \\
\hline \multicolumn{4}{|l|}{ Season: } \\
\hline 1985 , Wet $v$ dry season & $0 \cdot 25$ & 0.19 to 0.33 & $<0.0001$ \\
\hline 1986 , Wet $v$ dry season & $0 \cdot 30$ & 0.10 to 0.93 & $<0.05$ \\
\hline \multicolumn{4}{|l|}{ Altitude: } \\
\hline 1985, Lowland $v$ highland & 0.52 & 0.40 to 0.70 & $<0.0001$ \\
\hline 1986 , Lowland $v$ highland & $1 \cdot 13$ & 0.54 to 2.36 & $>0.05$ \\
\hline
\end{tabular}

that have occurred in Africa. The figures for mortality and nutritional state obtained in 1986 compare with those for African countries without acute food shortages. ${ }^{1730-32}$ Thus 1986 may be considered representative of a normal year in southern Ethiopia.

Rates of malnutrition and death remained high for several months in the shelter population. Experience from refugee shelters in Somalia and the Sudan shows that long periods of food aid were needed to normalise nutritional state. $^{45}$ Some studies from the Sudan showed that shelter conditions temporarily worsened the nutritional situation. ${ }^{5}$ Likely explanations for the comparatively high incidence of death in this study include crowding, limited supply of drinking water, and poor sanitation facilities. These factors promote the spread of infectious diseases such as respiratory tract infections, measles, and diarrhoeal diseases. Diarrhoea and measles may in turn cause the nutritional state to deteriorate, ${ }^{334}$ and malnourished children often experience infections. ${ }^{9}$

The association between malnutrition and mortality may, as my study indicates, be influenced by the social structure of the population. Furthermore, environmental factors such as geographical area and season seem to affect the incidence of death. Hence the association between malnutrition and risk of death is likely to be influenced by confounding variables, even during periods of famine. This may partially explain previous contradictory reports on the relation of anthropometric results to the risk of dying. . $^{15.18}$

My study indicates that children of families who move to emergency shelters from their homes during periods of drought are at an increased risk of death. This may be due to factors prevailing before, during, or after migration. Migration may occur mainly among families with sick children. The reasons why people migrate during famines are complex, but food shortage in itself is the main reason. In the Sudan, as de Waal reported, the threat of destitution rather than the risk of death influences people's response during a food emergency. ${ }^{35}$ Migration increases the risk of disease, ${ }^{36}$ and the nutritional state of children in famine relief shelters often deteriorates early in their stay. ${ }^{5}$ Thus, adequate food supplied early in a famine may reduce the scale of migration. If large scale migrations could be prevented the problem of rehabilitation of relief shelter populations may also be eased. These observations may have practical implications for future famine relief operations.

A study such as this has several limitations. Some deaths may have been missed, so that our figures may have been estimates of minimum death rates. In such a culturally homogenous population this bias is probably the same in all samples examined. It may be argued that the samples representing pastoralists are not totally representative of pastoralist communities because the sampling methods were not random. The pastoralist communities were, however, initially screened for moderately and severely malnourished children to select those most affected. These samples thus represent a possible bias towards overrepresentation of malnourished children among the pastoralists, and this would amplify the differences observed between stable pastoralist and agropastoralist societies and the shelter population, in which coverage was complete.

Our knowledge of drought prone populations in Africa is limited. We need more baseline information on food supply, nutritional state, and disease patterns. Specifically, more studies are needed of health and nutrition in relation to the changes now occurring in social and production systems of populations affected by drought.

1 Greene MH. Impact of the Sahelian drought in Mauritania, West Africa. Lancet 1974;i:1093-7.

2 Seaman J, Holt J, Rivers JP. The effects of drought on human nutrition in an Ethiopian province. Int 7 Epidemiol 1978;7:31-40.

3 Holt JF, Seaman J, Rivers JP. The Ethiopian famine of 1973-74. Harerge province. Proc Nutr Soc 1975;34:115-6A.

4 Toole MJ, Waldmann RJ. An analysis of mortality trends among refugee populations in Somalia, Sudan and Thailand. Bull WHO 1988;66:237-47.

Shears P, Berry AM, Murphy R, Nabil MA. Epidemiological assessment of the health and nutrition of Ethiopian refugees in emergency camps in Sudan, 1985. Br Med f 1987;295:314-8.

6 Mogues A. A famine relief operation at Qorem, Ethiopia, in 1966. Disasters 1981;5:6-18.

7 Belete S, Gebre-Medhin M, Hailemariam B, Maffi M, Vahlquist B, WoldeGebriel Z. Study of shelter population in the Wollo region. Environmental Child Health 1977; February:15-22.

8 Murray MJ, Murray MB, Murray AB, Murray CJ. Somali food shelters in the Ogaden famine and their impact on health. Lancet 1976;i:1283-5.

9 Tomkins AM. Protein-energy malnutrition and risk of infection. Proc Nutr Soc 1986;45:289-304.

10 Chandra RK. Nutrition, immunity, and infection: present knowledge and future directions. Lancet 1983;i:688-91.

11 Loutan L, Lamotte J-M. Seasonal variations in nutrition among a group of nomadic pastoralists in Niger. Lancet 1984; i:945-7.

12 Aaby P, Bukh J, Lisse IM, Smits AJ. Measles mortality, state of nutrition, and family structure: a community study from Guinea-Bissau. I Infect Dis 1983;147:693-701.

13 Prothero RM. Disease and mobility: a neglected factor in epidemiology. Int f Epidemiol 1977;6:259-67.

4 Victoria CG, Vaughan JP, Kirkwood BR, Martinez JC, Barcelos LB. Risk factors for malnutrition in Brazilian children: the role of social and environmental variables. Bull WHO 1986;64:299-309.

15 Bairagi R. A comparison of five anthropometric indices for identifying factors of malnutrition. Am $\mathcal{J}$ Epidemiol 1987; 126:258-67.

16 Chen LC, Alauddin AC, Huffman SL. Anthropometric assessment of energyprotein malnutrition and subsequent risk of mortality among preschool aged children. Am 7 Clin Nutr 1980;33:1836-45.

17 Smedman L, Sterky G, Mellander.I, Wall S. Anthropometry and subsequent mortality in groups of children aged 6-59 months in Guinea-Bissau. Am f Clin Nutr 1987;46:369-73.

18 Kasongo Project Team. Anthropometric assessment of young children's nutritional status as an indicator of subsequent risk of dying. $\mathcal{J}$ Trop Pediatr 1983;29:69-75.

19 Cossins NJ, Upton $M$. The impact of climatic variation on the Borana pastoral system. Agricultural Systems 1988;27:117-35.

20 Asmaron L. Gada: three approaches to the study of African society. New York: Free Press, 1973.

21 Helland $\mathrm{J}$. Five essays on the study of pastoralists and the development of pastoralism [Dissertation]. Bergen: University of Bergen, 1980

22 Hogg R. Pastoralism and impoverishment: the case of the Isiolo Boran of northern Kenya. Disasters 1980;4:299-310.

3 Central Statistical Authority, Ethiopia. Statistical abstract 1986. Addis Ababa: Central Statistical Authority, 1988

24 Lindtiorn B. Famine in Ethiopia 1983-85: kwashiorkor and marasmus in four regions. Ann Trop Paediatr 1987;7:1-5.

25 National Center for Health Statistics. Growth curves for children, birth-18 years. Washington, DC: National Center for Health Statistics, 1977.

26 World Health Organisation. Measuring change in nutritional status. Geneva: WHO, 1983. 
27 Norusis MJ. SPSS/PC+. Version 3.1. Chicago: SPSS Inc, 1989.

28 Armitage P, Berry G. Statistical methods in medical research. Oxford: Blackwell, 1987

29 Donaldson TJ. Pastoralism and drought. A case study of the Borana of southern Ethiopia [Dissertation]. Reading: University of Reading, 1986.

30 Bradley AK, Macfarlane SBJ, Moody JB, Gilles HM, Blacker JG, Musa BD. Malumfashi endemic diseases research project, XX. Demographic findings: mortality. Ann Trop Med Parasitol 1982;76:393-404.

31 Ethiopian Nutrition Institute. First round nutrition survey, October 1980. Addis Ababa: Ethiopian Nutrition Institute, undated.

32 Ethiopian Nutrition Institute, Vitamin A status of pre-school children in Ethiopia. An estimate of national prevalence. Addis Ababa: Ethiopian Nutrition Institute, undated.
33 Morley D, Woodland M, Martin WJ. Measles in Nigerian children. A study of the disease in west Africa, and its manifestations in England and othe countries during different epochs. F Hyg Camb 1963;61:113-34.

34 Rowland MG, Rowland SG, Cole TJ. Impact of infection on the growth of children from 0 to 2 years in an urban west African community. Am $\mathrm{f}$ Clin Nutr 1988;47:134-8.

35 De Waal A. Famine that kills. Darfur 1984-85. London: Save the Children 1988.

$36 \mathrm{Kloos} \mathrm{H}$. Health and resettlement in Ethiopia, with an emphasis on the 1984/85 resettement programme: a review. Ethioplan foumal 0 ment Research 1989;11:61-94.

(Accepted 7 September 1990)

\title{
Long term survival after intensive care
}

\author{
S Ridley, R Jackson, J Findlay, P Wallace
}

\begin{abstract}
Objective-To examine the long term survival of critically ill patients admitted to an intensive therapy unit and to ascertain the effects of age, severity of illness, and diagnostic category at admission on survival.
\end{abstract}

Design-Retrospective observational study with prospectively gathered data on all patients admitted to the unit between June 1985 and July 1987 and followed up until 1 January 1989.

Setting-Regional intensive therapy unit.

Patients -513 Critically ill adult patients, 16 of whom were excluded because measurements on severity of illness scoring were not available.

Main outcome measures-Age, severity of illness (determined with the acute physiology and chronic health evaluation (APACHE) II score), and diag nostic category on admission; deaths in the unit; and long term survival after discharge. Details of the survivors were sent to the Registrar General for Scotland, who issued copies of death certificates for the patients who had died between discharge and 1 January 1989.

Results-Of 497 patients, $119(24 \%)$ died in the intensive therapy unit and $120(24 \%)$ after discharge, leaving $258(52 \%)$ who were still alive at two years. The median (APACHE II) score was 13 and about half of the patients were aged 55 years or more. A wide range of critical illnesses, except neurosurgical emergencies, were treated. Survival analysis showed that only 41 (34\%) of 122 patients with an APACHE II score of $\geqslant 20$ were alive at one year $(95 \%$ confidence interval 25 to 42 ) compared with $124(80 \%)$ of 155 patients with a score of $<10(73$ to 87$)$. Of the 144 patients aged 65 or more, only $68(47 \%)$ survived to one year (39 to 55) but $90(83 \%)$ of the 109 patients aged between 18 and 34 survived a similar period $(76$ to 71). Mortality was also related to diagnostic category; $71 \%$ of trauma victims survived to one year compared with only $41 \%$ of those admitted with gastrointestinal pathology. Univariate analysis of the results showed that age, severity of illness, and diagnosis were all predictors of long term survival. Multivariate analysis, however, showed that only age and severity of illness were independent prognostic factors.

Conclusions-Long term survival of patients treated in an intensive therapy unit is related to severity of illness and to age. The outcome from critical illness in the elderly population is poor

\section{Introduction}

Nunn et $a l^{1}$ and Searle ${ }^{2}$ described studies of the long term survival of patients who had been ventilated after intensive therapy. There has, however, been no recent study examining the long term survival of all patients discharged from a typical British intensive therapy unit. If guidelines for admission to such units are to be developed as recently proposed by the King's Fund Institute $^{3}$ then accurate data about the long term survival and the factors influencing such survival are needed. The aims of this study were, firstly, to study the survival of a large cohort of patients admitted to an intensive therapy unit and, secondly, to test the effects of age, diagnostic category, and severity of illness on survival.

\section{Patients and methods}

All patients admitted to our intensive therapy unit between June 1985 and July 1987 were included in the study. The severity of illness of each patient on admission was assessed with the acute physiology and chronic health evaluation II (APACHE II) scoring system (appendix). ${ }^{4}$ The patient's age, the diagnosis necessitating admission, and the outcome of intensive treatment were recorded.

Details of patients discharged from the intensive therapy unit, including date of birth and national health number, were reported to the central register for the NHS (office of the Registrar General for Scotland). The registrar issued copies of the death certificates of those patients who had died between the date of their discharge and 1 January 1989. Thus, depending on the date of admission, patients were followed up for between 18 and 42 months after discharge.

Statistical analysis-The effects of age, severity of illness, and diagnostic group at admission on long term outcome were initially examined in a univariate analysis to give Kaplan-Meier survival curves and by log rank tests. This was followed by a multivariate analysis based on the Cox proportional hazards model. A stepwise backwards elimination method was used, and the models were fitted using the biomedical data program statistical package.

\section{Results}

During the two year study period 513 adult patients were admitted to the intensive therapy unit. Sixteen patients were excluded from the study because the required measurements for APACHE II scoring were unavailable. The registrar could not trace 12 of the patients because they had either left Scotland or were living elsewhere in the United Kingdom at the time of their critical illness; these patients were assumed to be still alive.

Of the remaining 497 patients, $119(24 \%)$ died in the unit and $120(24 \%)$ died after discharge, leaving 258 $(52 \%)$ alive at 1 January 1989 . Table I shows the age distribution of the patients, severity of illness, and diagnostic categories. About half of the patients admitted were aged 55 years or more. The median APACHE II score for the whole group was 13 and the 